\title{
Articles
}

\section{REAL AND NOMINAL CONVERGENCE AND THE NEW EU MEMBER STATES - ACTUAL STATE AND IMPLICATIONS}

\author{
Václav Žd'árek, Jaromír Šindel*
}

\begin{abstract}
:
This paper analyses the process of nominal and real convergence of the new Member States of the European Union. It also discusses theoretical and methodological issues relating to this process. The importance of nominal and real convergence is underlined in connection with a successful catching-up. The EU-10 economies experienced robust economic growth in recent years, which had a positive impact on the convergence process. Although this favourable development of real convergence (GDP per capita in PPS) is accompanied by a simultaneous price (nominal) convergence (changes in relative prices and a convergence of price levels), the comparative price level is still biased towards lower level in comparison with the per capita income.
\end{abstract}

Keywords: nominal and real convergence, Balassa-Samuelson effect, relative price level, competitiveness

JEL Classification: O11, E30, F15

\section{Introduction}

Expanding the European Union in May 2004 was the first step on the journey of the new Member States (EU-10) ${ }^{1}$ towards adopting the single currency. The subsequent steps are associated with meeting the Maastricht convergence criteria, which include aspects

* Centre for Economic Studies, University of Economics and Management, nám. I. P. Pavlova 3, CZ 12000 Praha 2 (vaclav.zdarek@vsem.cz, jara.sindel@centrum.cz)

The paper was compiled within the Research Centre Programme of the Ministry of Education, Youth and Sports, project No. 1M0524. The authors are grateful to V. Spěváček and R. Vintrová (CES VŠEM Prague), A. Ingianni (Kingston University, London) and participants of the $5^{\text {th }}$ INFER Workshop on International Economics: Trade, Factor Mobility and Convergence in Transition Economies, Kingston University, London, 14-16 July 2006 for helpful and valuable suggestions and comments on an earlier draft of this article. Remaining errors and omissions are only ours.

1 We focus on the new Member States without the new entrants from 2007 (Bulgaria and Romania). Many implications in this article are relevant only for the EU-4 states (the Visegrad group) and the Baltic states. 
of nominal and real convergence. Certain economists have serious concerns especially with regard to nominal convergence - as these countries become a part of the euro area, this may trigger adjustment processes that will effectively influence the price stability of the existing members of the euro area and this will logically lead to asymmetrical behaviour of the policy of the European Central Bank (ECB).

The EU-10 states (i.e. without Slovenia ${ }^{2}$, Malta and Cyprus ${ }^{3}$ ) are currently in a situation where in many cases a plan for introducing euro is in place and a preliminary date for joining the euro area has been set. ${ }^{4}$ A decision on when to join will need to be made in a few years time. The relevant countries will also be assessed by EU authorities as to whether they meet the determined criteria for entering the euro area. An analysis of the development in nominal and real convergence of economies including comparison is therefore highly relevant and necessary. Furthermore, experience with development before and after introducing euro in selected old EU Member States should not be ignored.

However, significant changes cannot be expected within just a few years. The economic standard will continue to grow at a slower pace over the next few years as the new Member States approach the level of the European Union. On the other hand, price (wage) levels and labour productivity should grow faster compared to the current rate to ensure smooth progress of integration in the euro area. These changes should arise from adjustment that does not lead to a high price (and subsequently wage) rise without the corresponding growth of labour productivity. Potential price and wage spiral would only ultimately lead to a fall in the real living standard and halt the convergence process. This is why the new Member States cannot be expected to reach the average European economic standard sooner than in a few decades. After all, even those less developed countries that joined the EU in the 1980s have not reached the economic or price level of other developed EU countries to this day. ${ }^{5}$

The reminder of the paper is organised as follows. The second part addresses selected theoretical and methodological issues associated with international comparison and convergence of economies in time. The third part includes empirical verification using data for the new and selected old EU Member States. Current problems of countries aiming to join the euro area are discussed in final part which presents as well as a brief summary of potential issues and problems.

2 Slovenia introduced euro on January 1, 2007.

3 The European institutions have already decided that Malta and Cyprus would join the euro area from January 1, 2008 - see the conclusions of the May 2007 Convergence Reports of the EC and ECB.

4 Some states have declared the date for euro adoption too (Slovakia in 2009, the Baltic states as soon as possible) in others this issue is still being discussed (Poland, Hungary and the Czech Republic) and the most often mentioned date is year 2012 or 2014.

5 The experience of united Germany illustrates the consequences of fast convergence (see Rother, Süppel, 2003). 


\section{Convergence - Theoretical Aspects}

Convergence is a process defined as approaching a certain level or decreasing a difference between two values over time (the difference between the two variables reduces over time towards a zero value). For example Greene (2003) presents rigorous theoretical definition. The meaning of the term nominal and real convergence according to individual authors is not without certain ambiguity. Real convergence is defined as approach of the economic standard towards the level of another developed country or a group of countries (within an integration group). It is usually measured by GDP per capita in the purchasing power parity ${ }^{6}$, which excludes the impact of different price levels and documents the actual volume of goods and services produces by the relevant economy. ${ }^{7}$

In the case of real convergence (the so-called absolute convergence concept), the theoretical foundation lies in the neoclassical growth theory, which assumes convergence towards a steady status (identical for all economies) influences by a variety of characteristics and parameters of the relevant economy (savings, population growth, degree of depreciation of the capital goods used, etc. $).{ }^{8}$ However, this theoretical concept did not provide satisfactory explanation to the tendencies observed in reality (catching up with developed countries by less developed countries). Empirical analyses carried out by individual studies produced a range of different and sometimes even contradictory results (see e.g. Barro, 1991, Barro-Sala-i-Martin, 2004). In reality, in many cases less developed countries remain at their lower levels and no convergence is observed or the gap between developed and less developed countries broadens. On the other hand, rapid convergence contradicting the theoretical assumptions of the neoclassical growth theory is observed in some other countries. This has led on the whole to the persisting necessity to seek alternative concepts and explanations.

A large number of new approaches explaining the phenomena observed in reality have been presented over the last two decades. Modern concepts of the endogenous growth theory have developed and reflect a range of additional up to now neglected factors, such as education of the population, institutional quality, etc. One permanent status for otherwise identical economies cannot exist due to these dissimilar qualities. These models can provide a theoretical description of empirically documented development of economies with a broader gap in the economic level that grow faster

6 GDP p.c. in the purchasing power parity reflects the country's economic standard in international comparison. When spatial comparison is carried out, volume indexes are expressed in the purchasing power parity to exclude price level differences. This indicator expresses the real "physical volume" of goods and services available to the relevant economy for consumption and investment (including the balance of foreign trade). It is necessary to distinguish between the PPS unit and PPP of the currency (e.g. US dollar) published by OECD (the USA are the reference country) or World Bank. PPS is an artificial unit created by EUROSTAT according to the average price level in the EU states and this is why its values vary even within individual EU countries. PPS is an artificial monetary unit created on the basis of euro and calculated from the average price levels in Member States (previously EU-15, currently EU-25) and thus practically fulfils the function of a double converter (prices and rate).

7 For instance, Slavík (2005) also understands real convergence as structural approaching between economies or technologies used.

8 For discussion of various convergence hypothesis see e.g. Galor (1996). 
than others. Some countries grow faster than others in spite of the achieved higher economic standard, while others may continue to lag behind (see e.g. Barro, Sala-i-Martin, 2004).

Nominal convergence is a process defined either in the broader sense as the convergence of absolute values and growth rates in connection with the Maastricht convergence criteria ${ }^{9}, i$. e. nominal values (interest rates, inflation rate, deficit and public debt, exchange rate criterion and criteria determined as a hypothetical standard for their fulfilment, see e.g. Vávra, 1999), or in the narrower sense as convergence of individual economies in their price (and economic) levels (see e.g. Frait, Komárek, 2004).

The mutual relationship between real and nominal convergence, $i . e$. the relationship between the economic standard achieved (GDP per capita) and the price level is bilateral, mutually influencing and determining (see e.g. Janáčková, 2000; Dobrinsky, 2006). Countries at a lower economic level typically have lower price and wage levels. As the economic standard increases, the price level tends to rise (due to inflation differential, as well as rising exchange rate). ${ }^{10}$

\section{Relationship between Price and Economic Level}

If the relatively strict assumptions of the PPP theory (Purchasing Power Parity, see e.g. Rogoff, 1996) were valid, prices of tradable goods in individual countries converted to one currency should by identical (international arbitration should lead to their harmonisation in the long run). Differences in the price levels would then be due to differences in the prices of non-tradable goods in the economy and their significance (relative weight), depending on the economic level achieved (income per capita, wage levels). A higher economic standard would imply a higher price level. The relationship between the price level and the economic standard should theoretically display positive correlation and this is often the case in practice (see e.g. Žd'árek, 2006).

However, in reality this relationship is disrupted by a number of factors. The most cited one is the existence of tradable and non-tradable goods (for definition see below), although differences between individual countries exist even within tradable goods. Despite this, empirical observations of the relationship between the price level and the economic standard often display certain interdependence of the two variables (see below) and confirm the theory mentioned above (see Balassa, 1964; Samuelson, 1964), which explains differences in the national price levels by different values of labour productivity in the tradable goods sector. For more detailed theoretical discussions and elaboration on the relationship referred to above, see e.g. Čihák, Holub (2001).

In reality, harmonising prices of goods and services in individual countries, i. e. enforcing the law of one price, or in the broader sense the theory absolute purchasing power parity is obstructed by a variety of factors. These obstacles are associated with

9 These criteria have been determined in order to assess development of economies striving to join the euro area, i.e. achieve "full and equal" position in respect of other EU Member States.

10 These processes gradually lead to the elimination of the cost-based competitiveness of local companies. If the economy is to retain its dynamics, progress towards non-price (qualitative) forms of competitiveness is necessary. 
free trade, the existence of transport and transaction costs, etc. ${ }^{11}$ Differences not only between non-tradable, but also between tradable goods are therefore observed in practice. (Goods are hereinafter used as a general term for goods as well as services.)

Exact differentiation between tradable and non-tradable goods is not intuitive, as it may seem at first. This differentiation is based on the fact that practically no good in the current economy is purely non-tradable as it contains a portion of tradable and a portion of non-tradable goods and services at its creation. The price differential of a particular product (or service) between the relevant countries and the cost of arbitration are also important factors. Only after a certain level of the difference between prices in individual countries is achieved, the relevant goods may be considered tradable (however, this negotiability is eliminated by the arbitration process itself). This differentiation is therefore an arbitrary issue and using terms such as "more or less tradable goods" and "more or less non-tradable goods" would appear more appropriate (see Skořepa, 2001, comp. Obsfeld, Rogoff, 1998). This differentiation of goods will be applied in the following text (despite the abbreviated reference as non-tradable goods being used).

However, not all economists see the problems in and discrepancies between the criteria of real and nominal convergence quite unambiguously (see Dědek, 2002). Frequently highlighted issue in the case of transitional economies with different economic structures and usually modified adjustment mechanisms, etc. is that excessive effort to promptly meet the required criteria for nominal convergence may have a significant impact on economic growth. ${ }^{12}$ (The previous statement is documented by the impact of the Balassa-Samuelson effect, hereinafter only as B-S effect. ${ }^{13}$ ) The situation when the country is about to join the monetary union, as it is in the case of the new EU Member States, is all the more significant.

Price structures of transforming economies are influenced to a great extent not only by the former regimes and pricing, but also by changes in prices associated with structural changes in the economy, changes in demand, etc. This naturally leads to adjustment of price relations depending on the flexibility of individual prices. If prices are inflexible downwards (and this is a phenomenon typical for most developed and transitional economies), this process results in an increase in the price level and a change in relative prices, which represent one of the reasons of price convergence of an economy.

Therefore economic growth generating pressure on the current account and inflation (B-S effect) associated with adjustment of relative prices and elimination of regulatory measures on one side occurs simultaneously with the reaction of stabilising policies supporting smooth progress or aiming to eliminate as many disrupting effects as

11 Overview of potential arbitration obstacles (see e.g. Skořepa, 2001; Égert, 2006).

12 A competitive relationship between economic growth and the rate of price increase within the relevant "corridor" is postulated. However, in view of new growth theories this assumption is no longer relevant.

13 Overview of literature and a more in-depth analysis of B-S effect (see e.g. Čihák, Holub, 2001; Holub, Čihák, 2003; Égert, 2003, 2006). 
possible on the other side. ${ }^{14}$ Values for the relevant criteria should therefore be used cautiously and the potential risks associated with their use should be highlighted during the progress of convergence. ${ }^{15}$

In this context it is necessary to realise that an excessively low inflation rate (due to problems with its measuring) may lead in a transitional economy to "smothering" of economic growth. On the other hand, "breaking" inflation expectations, which often include a very significant adapting element in their creation by economic entities, represent a serious problem for monetary authorities. Monetary authorities should therefore work with an estimated growth rate of productivity, expected distortion in the inflation rate calculation and the required criterion. Combining all of these aspects should lead to a compromise which will not influence the rate of real or nominal convergence. ${ }^{16}$

\section{Results and Discussion}

The empirical part discuss in greater detail on the actual development of real and nominal convergence during the period 1995-2005, for which the relevant data is available usually in two individual sections (1995-2000) and (2001-2006). The choice of these intervals was more of less arbitrary in order to distinguish between different stages of the actual development. Dividing the relevant period into sections 1996-1998 and 1999-2006 arising from the accession of selected countries to the euro area (introducing a joint currency) may present an alternative view on the issue.

\subsection{Real Convergence}

The Czech economy did not display a significant rate of real convergence (change only 7.0 p.p.) throughout the entire monitored period (see Table 1) and the rate achieved by the Czech economy is therefore slower by one half compared to that achieved by Hungary or Slovakia (however, the higher growth rate achieved by this economy is based on the growth from a lower basis) or one half of the rate reported by the

14 Flow of capital intended for financing the gap between savings and investments in the local economy may present a major problem. Naturally, this capital flow is a desirable phenomenon supporting the convergence process. Nonetheless, it is necessary to bear in mind that expansive monetary policy in connection with unsterilized inflow of capital may lead to problems with the Maastricht criteria.

15 As highlighted e.g. by Sorsa (2006).

16 In the case of the Czech Republic, the corridor determined in the past was relatively narrow. The current CNB target (3\%) is closer to the lower border line (given that the interval for price increase of $0-2 \%$ per year is considered price stability and additional $2 \%$ account for the impact of the B-S effect, this combination with exchange rate appreciation by $0.5 \%$ meets the potential ECB target of $2 \%+1.5 \%$ ). Therefore, in combination with exchange rate changes the price growth appears consistent. Problems in the evaluated stage will occur if three economies report zero (or even negative) growth in prices. In this case the criterion limit could be $1.5 \%$ or lower. However, according to official EU materials this outcome is not possible (see EC, 2005, p. 20). Similar conditions apply to the minimum period required for remaining in the ERM-II (exchange rate appreciation is allowed). For an alternative opinion see Janáček, Janáčková (2004). 
comparable Slovenia (given that the specific development in Cyprus, Malta and the Baltic states is disregarded). Examination of the development in two individual periods reveals that this generally very weak result is influenced by the development during the first stage (1995-2000), in particular by the $2^{\text {nd }}$ recession during 1997-1999.

Table 1

GDP per capita, in Selected EU Countries, 1995-2006 (EU-25 = 100)

\begin{tabular}{|c|c|c|c|c|c|c|}
\hline & \multirow{2}{*}{$1995^{1)}$} & \multirow{2}{*}{2000} & \multirow{2}{*}{2006} & \multicolumn{3}{|c|}{ Change (p.p.) } \\
\hline & & & & 1995-2006 & 1995-2000 & 2000-2006 \\
\hline Czech Republic & 69.0 & 64.7 & 76.0 & 7.0 & -4.4 & 11.3 \\
\hline Hungary ${ }^{2)}$ & 49.0 & 53.7 & 63.4 & 14.4 & 4.7 & 9.7 \\
\hline Poland & 41.2 & 46,8 & 51.2 & 9.9 & 5.5 & 4.5 \\
\hline Slovakia & 44.5 & 47.3 & 60.2 & 15.6 & 2.7 & 12.9 \\
\hline Slovenia & 68.4 & 72.6 & 83.3 & 14.9 & 4.2 & 10.7 \\
\hline$E U-5^{3)}$ & 50.2 & 52.5 & 60.4 & 10.2 & 2.4 & 7.9 \\
\hline Estonia & 33.5 & 42.3 & 65.0 & 31.5 & 8.7 & 22.8 \\
\hline Lithuania & 34.2 & 37.8 & 54.9 & 20.7 & 3.6 & 17.1 \\
\hline Latvia & 29.7 & 35.3 & 53.3 & 23.6 & 5.6 & 17.9 \\
\hline$E \boldsymbol{U}-\boldsymbol{8}^{3)}$ & 48.9 & 51.4 & 60.1 & 11.2 & 2.5 & 8.6 \\
\hline Cyprus & 81.9 & 82.1 & 88.2 & 6.3 & 0.2 & 6.1 \\
\hline Malta & .. & 78.1 & 71.5 & .. & .. & -6.6 \\
\hline$E U-10^{3)}$ & .. & 52.1 & 60.6 & .. & .. & 8.4 \\
\hline Portugal ${ }^{4)}$ & 75.5 & 80.1 & 70.3 & $-3,9$ & 5,8 & $-9,7$ \\
\hline Greece & 71.0 & 72.6 & 85.0 & 14.0 & 1.7 & 12.3 \\
\hline
\end{tabular}

Note: ${ }^{1)}$ EUROSTAT estimate, ${ }^{2)}$ Hungary changed the methodology for measuring of GDP since 2002 (allocation of FISIM to user sector/industries), thus its figures aren't compatible with other states of the EU-25. ${ }^{3)} \mathrm{EU}-5$, EU-8 and EU-10 are weighted averages. ${ }^{4)}$ Break in time series in 2003.

Source: EUROSTAT, Structural Indicators (June, 2007), own calculation.

A positive turnaround occurred in the second period (during 2000-2006), when the $\mathrm{CR}$ reported the second greatest real convergence dynamics of the EU-5 states (about 1.6 p.p. behind Slovakia), followed by Slovenia and Hungary. Poland reported very slight growth at the beginning of the new century due to certain macroeconomic problems. The high increase of GDP in Slovakia over the last few years was not reflected in real convergence for a number of reasons, which included the effect of fixed prices used in GDP calculation (for more details on the issue of reported and actual convergence rates for economies see the section dedicated to convergence in the study Spěváček et al., 2005).

The following Figure1 and Figure 2 show the economic levels of individual EU-10 countries during the period 1999-2006. Figure 1 presents an overview of changes in the economic levels of individual countries, while Figure 2 illustrates the same development in relation to the EU-25. Development in the EU-15 is included in both figures for comprehensive outlook. 


\section{Figure 1}

Economic Level (GDP per capita) in EU-10 Countries and EU-15 $(E U-25=100)$

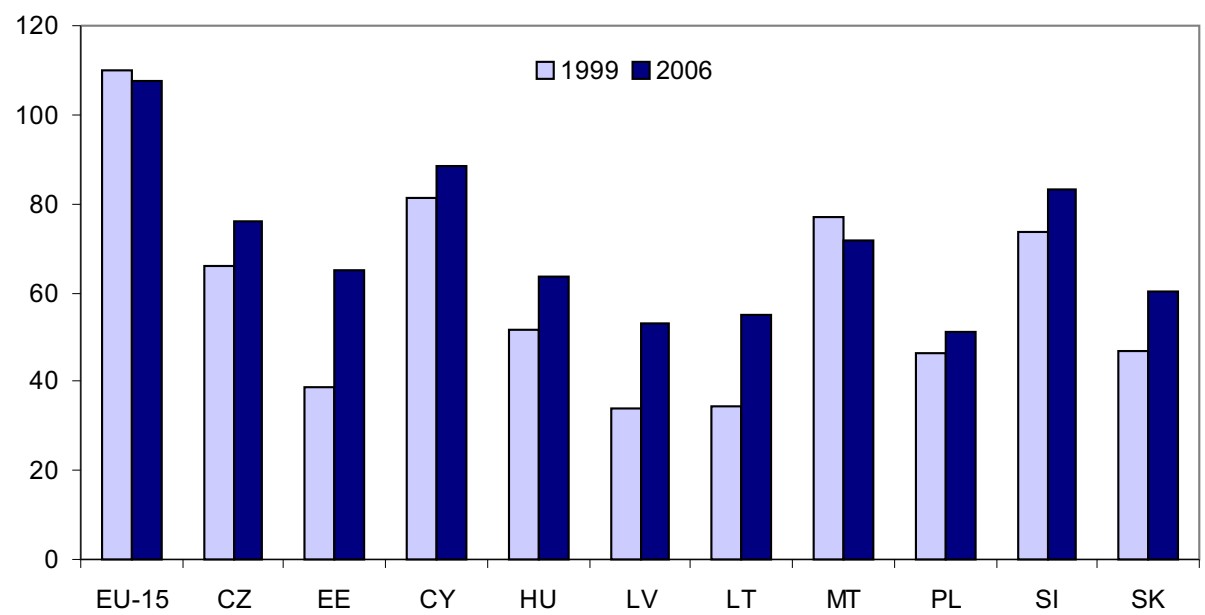

Figure 2

Changes in GDP per capita in PPS in EU-10 Countries and EU-15 in Comparison with the EU-25, 1999-2006

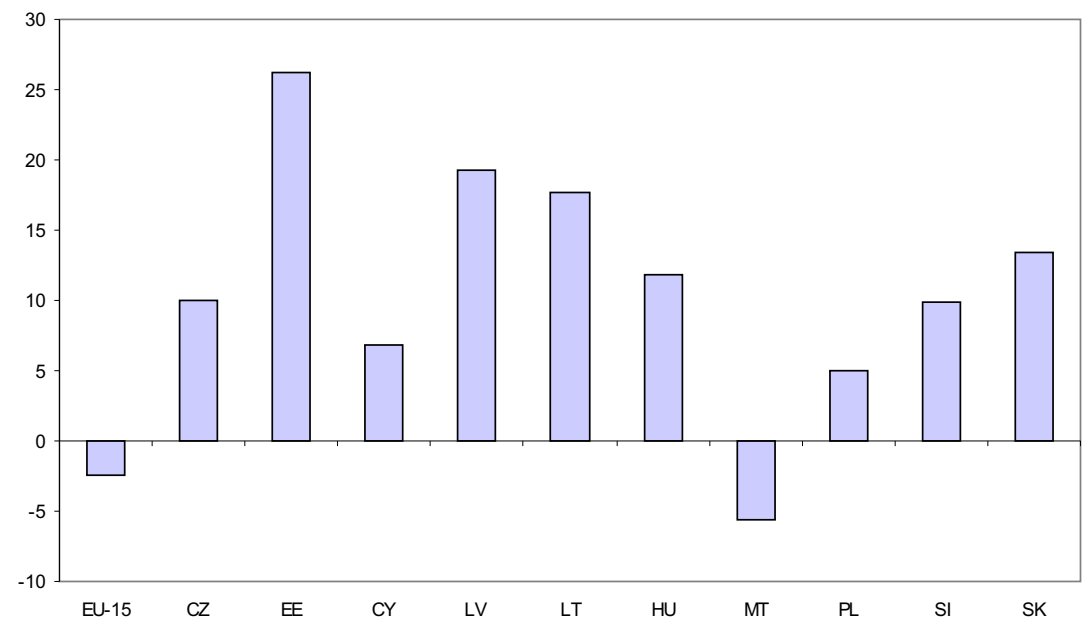

Note: Data for 2006 are preliminary.

Source: EUROSTAT. Structural Indicators, National Accounts (June, 2007), own calculation.

Figure 3 illustrates the frequently used relationship between the economic standard and price level of all EU countries. The correlation between the economic standard (expressed by GDP per capita in PPS) and the price level of the overall GDP in the EU-25 group is very close. The slope of the regression line (0.82) is relatively close to one and as previously theoretically shown (see Čihák, Holub, 2001, p. 335), a unit slope of the line is not a condition because its value is influenced by the portion of 
non-tradable goods in GDP and the share of the capital used for producing non-tradable goods. The explanatory capacity of this simple OLS regression is relatively high (89\%).

Figure 3 shows that the price level of the Czech economy is apart from the price level of the European Union downwards far more than a distance corresponding with the difference in the economic standard would be. The Czech economy (and Slovenia) differs from economies of other new Member States in this regard as their distance from the EU-25 price level in most cases matches their economic standard. The price levels of other economies are directly on the regression line, suggesting correlation between the economic standard and the price level, or very near the line (for discussion of possible causes see below). Northern European countries, France and Germany stand out from the group of the most developed EU countries - their price level displays upward divergence, while Belgium, Ireland, the Netherlands and Austria depart from the overall EU level downwards.

\section{Figure 3}

Relationship between Price and Economic Level, $2006(E U-25=100)$

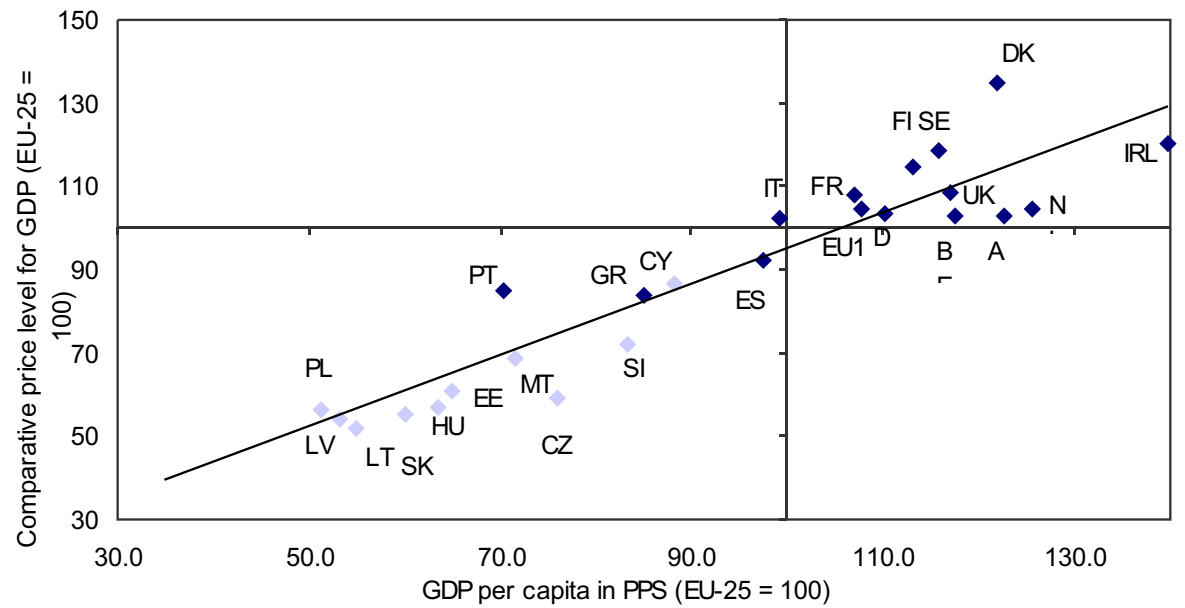

Note: Luxemburg is omitted from the analysis. Linear regression: $C P L=10.042+0.8273 \cdot G D P, \mathrm{R}^{2}=0.890, \mathrm{~F}$-test $=227.849$, D-W test $=2.086$.

Source: EUROSTAT, Structural Indicators, National Accounts (June, 2007), own calculation.

The change in the economic and price level in the EU-10 countries recorded in the following Figure 4 is also interesting for our purposes. The figure clearly shows a group of countries displaying growth in their economic standards, as well as the price levels (the first quadrant). Applying an imaginary diagonal $\left(45^{\circ}\right.$ line) to the quadrant reveals differentiated development between the Baltic states (real convergence is faster than nominal convergence) and the CR, Hungary a Slovakia (nominal convergence is faster than real convergence). Only Malta (price increase and economic divergence) and Slovenia (stagnation of the price level and real convergence) display significantly different development. 


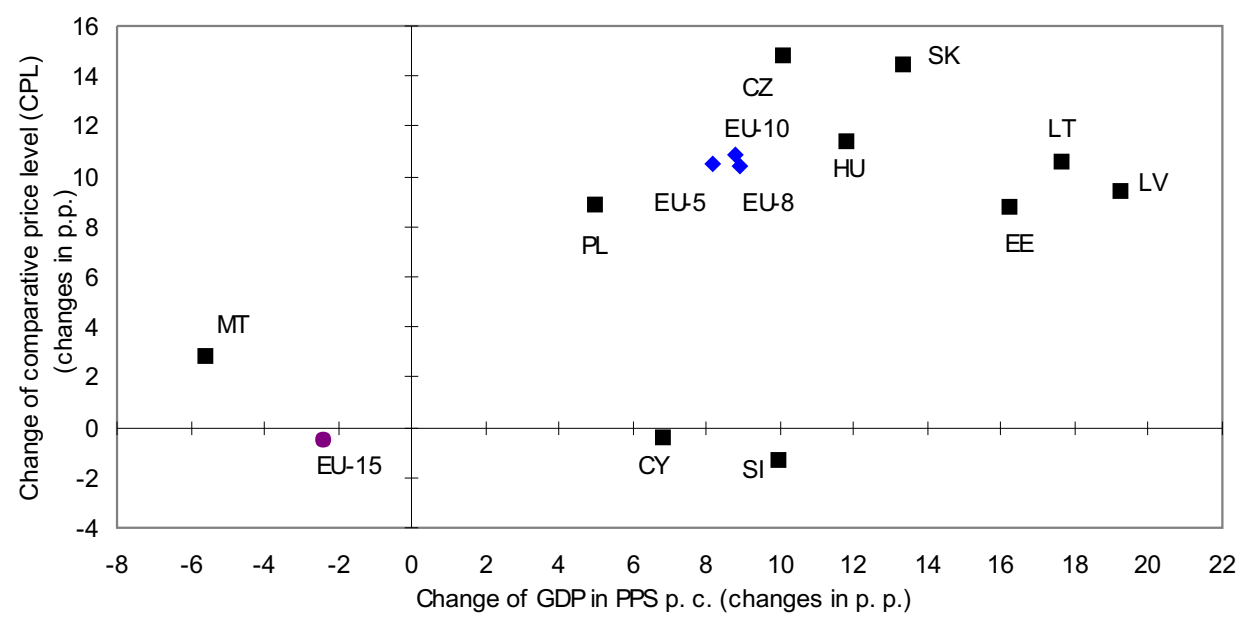

Source: EUROSTAT, Structural Indicators, National Accounts (June, 2007), own calculation.

Table 2 summarises a different outlook of the changes in the comparative price levels for GDP in both new EU and selected old Member States. It shows that during the period 1995-2005 only one economy displayed a decrease in the price level (Slovenia by 1.7 p.p.), very slight growth was recorded in Cyprus (1.5 p.p.). The Czech Republic recorded growth by 20.7 p.p., which is about 6 p.p. above the change in the price level growth observed in Slovakia (14.6 p.p.). While the growth in the CR was distributed relatively more evenly, significant growth in Slovakia or in Hungary occurred over the last six years (2000-2006).

When the price level of the Czech economy is used as the basis, its expression in relation to the other EU-5 countries generates interesting results. The standard of the Czech economy is somewhat higher than that of Poland and Slovakia and this is consistent with the achieved higher economic level. On the other hand, the difference between price and economic level in the CR compared to Hungary and Slovenia is higher. On the contrary, the price level in Poland is higher that its economic level over the whole period in question. (The same phenomenon can be observed in the case of the Baltic states.) The negative difference was turned into positive in case of Hungary in recent years. The very fast growth in the price level in Hungary would be worth analysing in detail in order to find causes that led to this development even though it was significantly corrected in the last years (about 3.4 p.p.). ${ }^{17}$ Interestingly, the growth in

17 The fact that many Austrian residents have commuted to Hungary over many years in order to make use of the local cheaper services may be one of the possible explanations. This may have pushed the local prices up to an extent reflecting in the overall price level. Data on the price level development would be required for confirming these conclusions. 
Poland (up to 2000) followed by a significant swing in the price level (according to data available the price level for 2001 was almost $58 \%$, in 2004 only $48.3 \%$ and in 2006 surpassed the level of $56 \%$ again) is also very interesting. Development in two less developed EU countries (Portugal and Greece) was included for comparison.

Table 2

Comparative Price Level for GDP, in Selected EU Countries, 1995-2006 (EU-25 = 100)

\begin{tabular}{|c|c|c|c|c|c|c|c|}
\hline & \multicolumn{3}{|c|}{ CPL } & \multicolumn{3}{|c|}{ Change in CPL (p.p.) } & \multirow{2}{*}{$\begin{array}{l}\text { Czech Republic } \\
=100(2006)\end{array}$} \\
\hline & 1995 & 2000 & 2006 & 1995-2006 & 1995-2000 & 2000-2006 & \\
\hline Czech Republic & 38.3 & 46.0 & 59.1 & 20.7 & 7.6 & 13.1 & 100.0 \\
\hline Hungary ${ }^{1)}$ & 43.5 & 47.0 & 56.7 & 13.2 & 3.6 & 9.7 & 96.0 \\
\hline Poland & 43.7 & 51.7 & 56.1 & 12.5 & 8.1 & 4.4 & 95.0 \\
\hline Slovakia & 40.5 & 43.0 & 55.1 & 14.6 & 2.4 & 12.2 & 93.3 \\
\hline Slovenia & 73.8 & 71.6 & 72.1 & -1.7 & -2.2 & 0.5 & 122.0 \\
\hline$E U-5^{2)}$ & 43.5 & 50.0 & 57.5 & 14.0 & 6.5 & 7.4 & $x$ \\
\hline Estonia & 38.1 & 52.6 & 60.8 & 22.7 & 14.5 & 8.2 & 103.0 \\
\hline Lithuania & 25.7 & 46.3 & 51.9 & 26.2 & 20.6 & 5.6 & 87.9 \\
\hline Latvia & 32.9 & 50.4 & 54.0 & 21.1 & 17.5 & 3.6 & 91.4 \\
\hline$E \boldsymbol{U}-\boldsymbol{8}^{2)}$ & 42.5 & 50.0 & 57.2 & 14.7 & 7.4 & 7.2 & $x$ \\
\hline Cyprus & 85.3 & 87.8 & 86.8 & 1.5 & 2.6 & -1.1 & 146.9 \\
\hline Malta & .. & 68.9 & 68.7 & .. & .. & -0.3 & 116.2 \\
\hline$E U-10^{2)}$ & .. & .. & 60.7 & .. & .. & 7.8 & $x$ \\
\hline Portugal ${ }^{3)}$ & 73.9 & 74.1 & 84.7 & 10.8 & 0.1 & 10.7 & 143.4 \\
\hline Greece & 76.9 & 78.9 & 83.9 & 7.0 & 2.0 & 5.0 & 142.0 \\
\hline
\end{tabular}

Note: ${ }^{1)}$ Hungary changed the methodology for measuring of GDP since 2002 (allocation of FISIM to user sector/industries), thus its figures aren't compatible with other states of the EU-25. ${ }^{2)} \mathrm{EU}-5$, EU-8 and EU-10 are weighted averages. ${ }^{3)}$ Break in time series in 2003.

Source: EUROSTAT, National Accounts (June, 2007), own calculation.

The implications for nominal convergence are more than obvious. While real convergence in the selected EU-10 countries during the current period has developed significantly better than in the previous period and the Czech economy is progressing towards a leading position among these catching-up economies, nominal convergence lags behind. Figure 4 illustrates this discrepancy and shows a clear downward divergence in the CPL in the case of the Czech economy, which is a situation worthy more detailed discussion. ${ }^{18}$

18 Improvement in terms of trade (T/T), when prices of exported goods and services grow faster than import prices, is another issue this paper chooses not to address. The CR has the most positive development of T/T within the EU-25 (except for Lithuania); T/T for the CR increased by $12 \%$ between 1995 and 2004. Slovenia was also among the EU-5 countries with positive long-term development of T/T. By contrast, Poland and Slovakia experienced strongly negative development of T/T, in particular during the period before 2000 or 2001, see e.g. Vintrová (2005). 


\subsection{Selected Circumstances of Nominal and Real Convergence}

Unlike in the case of other new EU Member States (Hungary, Poland or Slovakia), a significant characteristic of the Czech economy has been a long-term downward deviation in the price level from the expected (theoretical) value. ${ }^{19}$ As there are a few types of consequences associated with this phenomenon, ${ }^{20}$ the following text mentions selected consequences only. The relationship between the real and nominal convergence process has been often matter of the analysis (see Figure 3). We used also the disaggregated approach and analysed the relationship between real convergence process derived from GDP per capita in PPS and the disaggregated nominal convergence process quantified by comparative price levels for total services (see Figure 5) and total goods (see Figure 6).

\section{Figure 5}

Comparative Price Level for Total Services in 2000 (up) and 2005 (down)
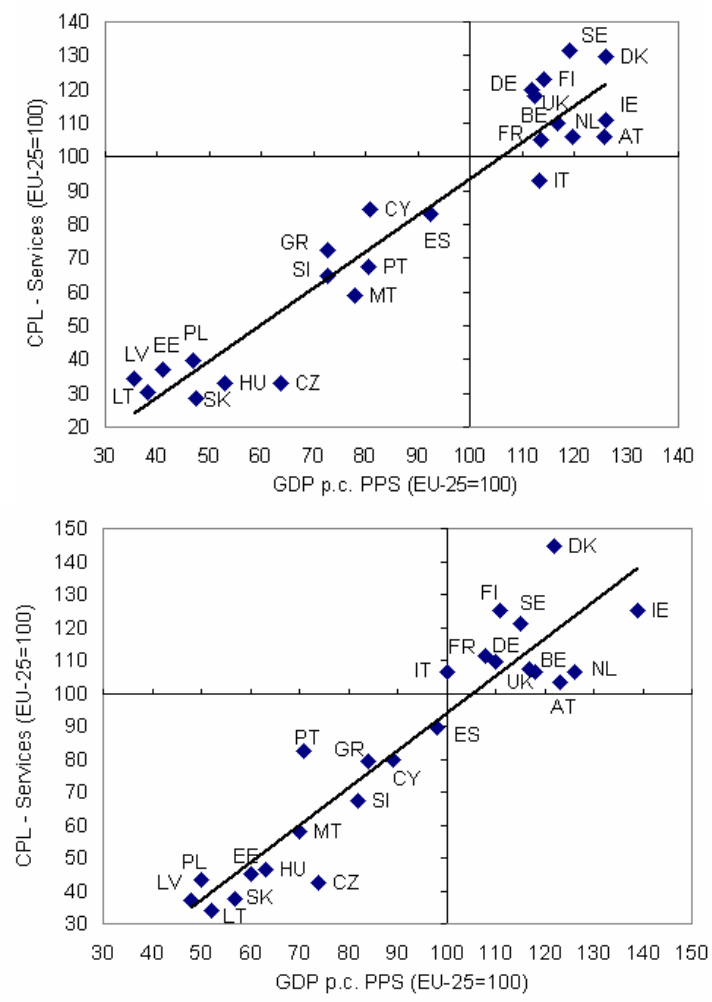

Note: Luxembourg is omitted. Linear regression: $C P L=-14.2+1.08 \cdot G D P, R^{2}=0.91$ in 2000 and $C P L=-19.8+$ 1.14.GDP, $R^{2}=0.87$ in 2005 .

Source: EUROSTAT, Economy and Finance, Prices (June, 2007), own calculation.

19 However, for example Croatia recorded a completely opposite status - the price level was higher than the economic standard, see Nestić (2005). Turkey, Switzerland and Norway or outside Europe New Zealand and Mexico present some more different examples.

20 Some are mentioned e.g. in an article by Janáčková (2000). 
From simple linear regression we got absolutely different results. The slope of CPL for total services is more than 1 and the slope for total goods is between 0.5 and 0.6 (the slope of CPL for GDP is below 1). It can be roughly explained by the tradability of goods and services, but we can also perceive differences among new Member States from the change of CPL.

Figure 6

Comparative Price Level for Total Goods in 2000 (up) and 2005 (down)
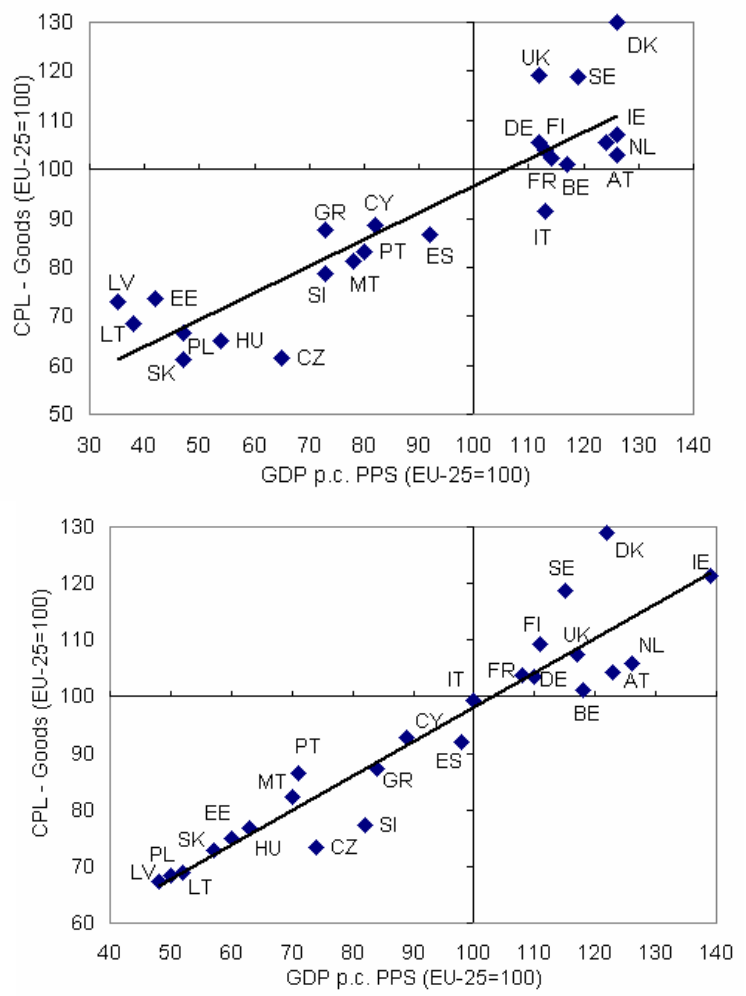

Note: Luxembourg is omitted. Linear regression: $\mathrm{CPL}=42.0+0.55 \cdot \mathrm{GDP}, \mathrm{R}^{2}=0.81$ in 2000 and $\mathrm{CPL}=37.3+$ $0.61 \cdot \mathrm{GDP}, \mathrm{R}^{2}=0.89$ in 2005 .

Source: EUROSTAT, Economy and Finance, Prices (June, 2007), own calculation.

The CPL for total services in new Member States is joined with the continuing real convergence process. As comparative price level for total goods is not connected with the real convergence process (see Figure 6 and Figure 7), we cannot expect the substantial increase in CPL for total goods during the progress in real convergence process. This is supported for new Member States by Figure 7, where the change of the real convergence process is joined with the change of the CPL for total services. But it does not hold for the change of the CPL for total goods. 


\section{Figure 7}

Change in GDP (per capita in PPS) and Comparative Price Level for Total Services (up) and for Total Goods (down) between 2000 and 2005
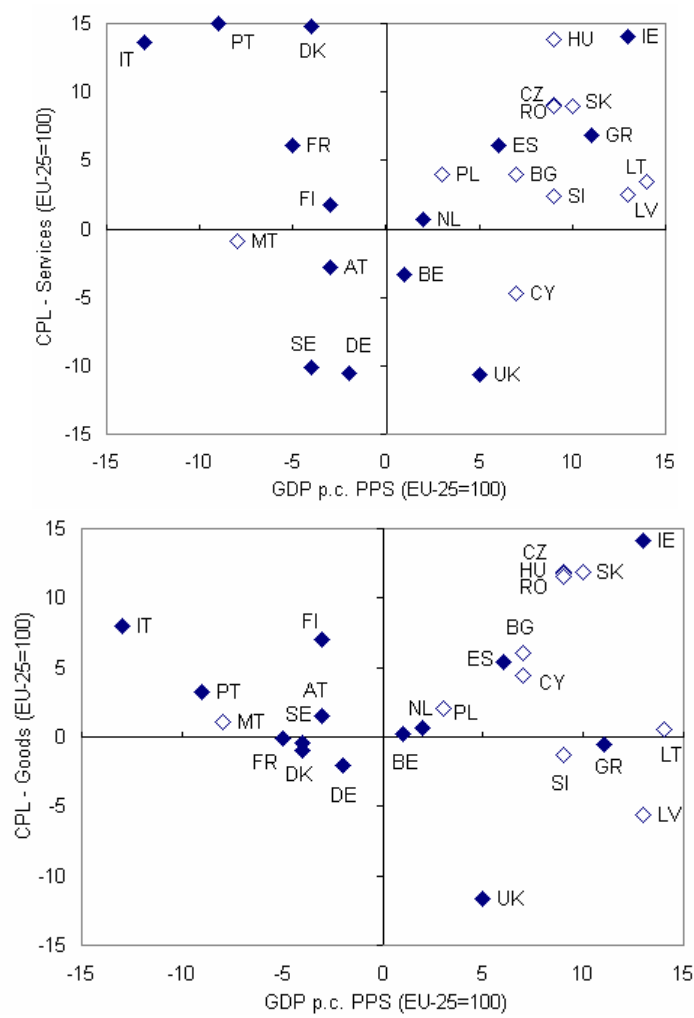

Note: Luxembourg is omitted.

Source: EUROSTAT, Economy and Finance, Prices (June, 2007), own calculation.

By examining the nominal convergence process we do not want to focus only on the levels of new Member States, but also explore the comparative price level index for disaggregated levels and different group of countries. The continuing real and nominal convergence process among the EU-25 Member States is visible from Table 3. The standard deviation of the CPL index ${ }^{21}$ for GDP declines from 27.5 in 2000 to 25.4 in 2005 in the EU-25 and is much higher than in the EU-15 (13.4) or in the euro area Member States (11.1). These differences are mainly caused by the CPL for total services (compare 33.2 for total services with 17.7 for total goods), by the CPL for government final consumption expenditure (compare 35.2 with 24.4 for households final consumption expenditure or with 19.6 for gross fixed capital formation). Origins of the different CPL result from the role of non-tradable in the service sector and the role of a government (regulated prices and non-tradability in government sector).

21 Eurostat publishes the price convergence indicator, what is the coefficient of variation of comparative price level index for final household consumption in \%. 
By analysing the standard deviations for disaggregated levels, we can also notice its increase for the gross fixed capital formation (capital goods) and durable goods, however their CPL have the lowest standard deviation among the EU-25 Member States (19.6 and 13.9 respectively). For the new Member States and especially for the post-transition countries (NMS-4) the increase in the standard deviation, which is visible in almost all spheres of CPL, is also interesting. The highest differences between standard deviations are in CPL for gross fixed capital formation (capital goods) and total goods both in 2000 and in 2005 (CPL decreased in Poland in comparison with increase in the Czech Republic, Hungary and Slovakia). Such a different development confirms very low increase of CPL for Poland from the Table 2. As was noted the standard deviation of CPL is much higher among EU-25 than among the euro area Member States, but we can also observe two stable groups from Table 3 - the euro area (EU-12) and new Member States (NMS-10) with the similar standard deviation levels.

Table 3

Progress in Convergence Process

\begin{tabular}{|l|r|r|r|r|r|r|r|r|}
\hline \multirow{2}{*}{ GDP p.c. in PPS } & \multicolumn{2}{|c|}{ EU-25 } & \multicolumn{2}{c|}{ EU-12 } & \multicolumn{2}{c|}{ NMS-10 } & \multicolumn{2}{c|}{ NMS-4 } \\
\cline { 2 - 8 } & $\mathbf{2 0 0 0}$ & $\mathbf{2 0 0 5}$ & $\mathbf{2 0 0 0}$ & $\mathbf{2 0 0 5}$ & $\mathbf{2 0 0 0}$ & $\mathbf{2 0 0 5}$ & $\mathbf{2 0 0 0}$ & $\mathbf{2 0 0 5}$ \\
\hline Comparative Price Level - GDP & 31.4 & 27.3 & 17.5 & $\mathbf{1 8 . 4}$ & 16.3 & 13.2 & 7.4 & $\mathbf{8 . 8}$ \\
\hline Actual Individual Consumption & 27.5 & 25.4 & 12.8 & 11.1 & 13.9 & 11.0 & 3.2 & 2.6 \\
\hline Actual Collective Consumption & 29.3 & 27.2 & 13.6 & 12.0 & 15.8 & 12.7 & 3.8 & 2.5 \\
\hline Gross Fixed Capital Formation & 36.1 & 33.4 & 17.6 & 14.6 & 18.9 & 14.9 & 4.2 & $\mathbf{4 . 4}$ \\
\hline Final consumption expenditure & 19.7 & 19.6 & 12.3 & $\mathbf{1 2 . 9}$ & 6.2 & 4.4 & 2.7 & $\mathbf{4 . 7}$ \\
\hline Household final consumption expenditure & 30.2 & 28.0 & 14.0 & 12.2 & 16.3 & 13.0 & 3.9 & 2.7 \\
\hline Government final consumption expenditure & 26.7 & 24.4 & 13.6 & 11.5 & 14.2 & 10.8 & 4.5 & 2.3 \\
\hline Total goods & 38.1 & 35.2 & 18.3 & 14.7 & 20.7 & 17.3 & 2.8 & $\mathbf{4 . 1}$ \\
\hline Consumer goods & 19.2 & 17.7 & 8.4 & $\mathbf{9 . 6}$ & 8.5 & 7.2 & 2.3 & $\mathbf{3 . 0}$ \\
\hline Non-durable goods & 19.8 & 17.2 & 7.9 & $\mathbf{8 . 2}$ & 11.9 & 10.6 & 3.1 & 2.1 \\
\hline Semi-durable goods & 23.4 & 20.8 & 10.4 & $\mathbf{1 1 . 7}$ & 11.8 & 11.6 & 3.3 & 1.5 \\
\hline Durable goods & 15.0 & 10.4 & 7.8 & 6.3 & 10.1 & 6.9 & 4.3 & $\mathbf{5 . 8}$ \\
\hline Capital goods & 13.9 & 13.9 & 7.4 & 6.7 & 14.3 & 11.0 & 2.7 & 1.1 \\
\hline Total services & 19.7 & 19.6 & 12.3 & $\mathbf{1 2 . 9}$ & 6.2 & 4.4 & 2.7 & $\mathbf{4 . 7}$ \\
\hline Consumer services & 35.4 & 33.2 & 17.6 & 14.4 & 17.7 & 14.1 & 4.0 & 3.3 \\
\hline Government services & 33.8 & 31.6 & 19.3 & 15.6 & 16.1 & 11.5 & 5.5 & $\mathbf{3 . 7}$ \\
\hline Collective services & 38.1 & 35.2 & 18.3 & 14.7 & 20.7 & 17.3 & 2.8 & $\mathbf{4 . 1}$ \\
\hline Individual services & 36.1 & 33.4 & 17.6 & 14.6 & 18.9 & 14.9 & 4.2 & $\mathbf{4 . 4}$ \\
\hline & 39.6 & 36.7 & 19.3 & 15.5 & 22.6 & 19.5 & 1.8 & $\mathbf{4 . 3}$ \\
\hline
\end{tabular}

Note: The standard deviation of levels $(E U-25=100 \%)$. NMS-10 = New Member States. NMS-4 = the Czech Republic, Hungary, Poland and Slovakia. The number in 2005 is in bold, if the standard deviation is higher than in 2000. Capital goods correspond with Gross fixed capital formation and Government services with the Government final consumption expenditure.

Source: EUROSTAT, Economy and Finance, Prices (June, 2007), own calculation.

The analysis on disaggregated level is concluded by the role of government services. Figure 8 offers surprising view on the role of government services in the CPL analysis. The CPL for government is the highest relatively to consumer services in the Czech 
Republic, Hungary and Slovakia in 2000 and 2005. These three countries have also the lowest CPL for GDP and actual individual consumption in comparison with GDP per capita in PPS. The solution of this paradox is beyond the scope of this analysis, but we offer the possible explanation through the regulated prices in next section.

Figure 8

Relative CPL of Government and Consumer Services with Total Services CPL in 2000 (up) and 2005 (down)
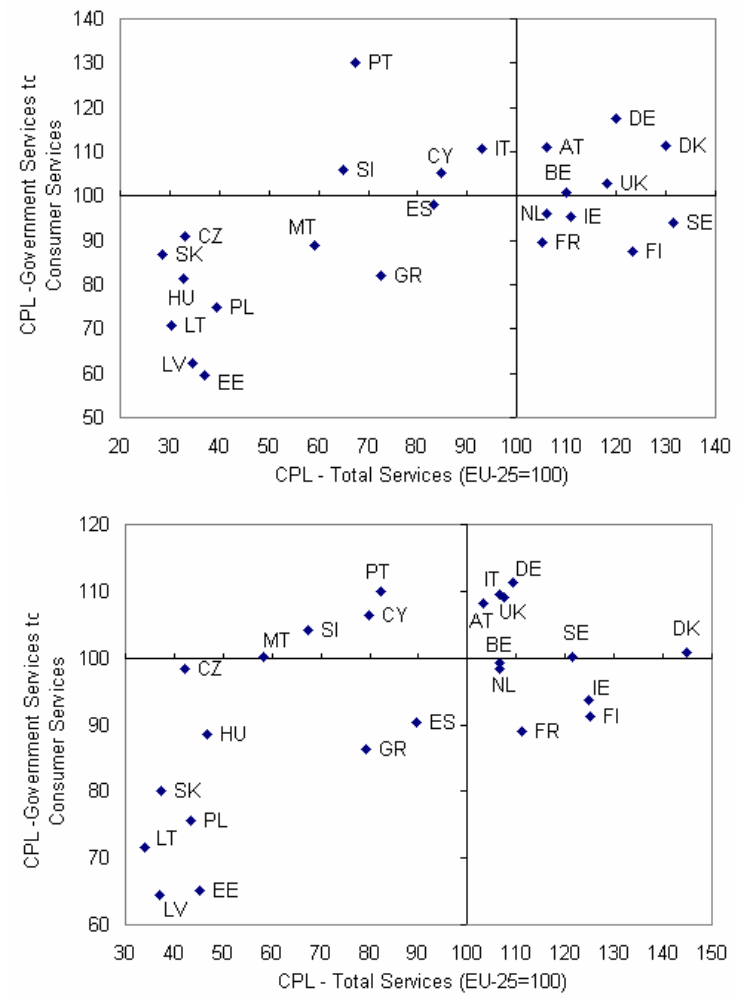

Note: Luxembourg is omitted.

Source: EUROSTAT, Economy and Finance, Prices (June, 2007), own calculation.

\subsection{Why Are the Differences So Significant?}

Price adjustment in an open economy is determined to a significant extent by autonomous factors whose strength arises from the share of administered prices in the relevant economy. Development of the price level therefore needs to be considered in the context of price differences between tradable and non-tradable goods and in the context of regulated items.

Prices of tradable goods are regulated in principle by international competition and the influence of domestic conditions is relatively insignificant. Prices of some of these commodities may be at an international level, while other prices may be above or below 
this level. ${ }^{22}$ Therefore, their development may be influenced by many other factors and these prices may not change much although different movement arising from price divergence will be observed in other prices. It is important that the price convergence displays differentiated development in principle reflecting different development in tradable and non-tradable groups (or subgroups) of goods, inputs and outputs because only then the competitiveness of domestic producers can be sustained on a long-term basis.

Non-tradable goods have a price low level arising from the past conditions and this level grows very slowly as the economic standard and the wage level increases. This growth should not be irrespective of development in the labour productivity as this could lead to consequences identical to those experienced currently by the states of the former East Germany. Long-term adjustment process can be expected and it is impossible to reasonably predict that the $\mathrm{CR}$ will successfully reach a level similar to that of other EU countries. After all, even other EU countries display significant deviations in this area many years after their accession.

Different shares of regulated prices in EU-8 countries may also be partially responsible for the observed situation. The CR and Slovakia are currently the two countries with the highest share of regulated prices in the consumer basket for inflation calculation (see Table 4). Although this consumer basket is different from values of these items in the national accounts, it can be seen as certain approximation of the actual values, given that the distortion will not be very significant (considering the consumer basket structure based on selective identification of household consumption).

Table 4

Composition of the Consumer Basket (HICP)

\begin{tabular}{|l|c|c|c|c|c|c|c|c|}
\hline & CR & EE & HU & LT & LV & PL & SI & SK \\
\hline Regulated prices & 250.5 & 178.0 & 200.6 & 171.3 & 205.9 & 206.0 & 166.9 & 258.2 \\
\hline Other prices & 749.5 & 822.0 & 799.4 & 828.7 & 794.1 & 794.0 & 833.1 & 741.8 \\
\hline
\end{tabular}

Note: total index $=1000$.

Source: WB (2006), p. 12, own adaptation.

The shares of administered items in national consumer baskets for CPI calculation differ significantly among individual new Member States - for example in 2005 from a few per cent (Poland) to tens of per cent (Estonia) - see Table 5.

22 In the CR this is the case for example in the prices of clothes in 2003 (CPL index $=105$ ), 8th place above the EU level shared with Cyprus; while other EU-10 countries are below the EU level (see EUROSTAT, 2005a). On the other hand, the local prices of passenger cars for 2004 were below the EU level (CPL index $=90)$, Hungary recorded a somewhat higher level (97); while lower levels were observed in Slovakia (88) and Poland (82) (see EUROSTAT, 2006a). 
Table 5

The Share of Administered Prices in the CPI (in \%)

\begin{tabular}{|c|c|c|c|c|c|c|c|c|}
\hline & CR & EE & HU & LT & LV & PL & SI & SK \\
\hline 1998 & 13.3 & 25.6 & 17.0 & 16.9 & 20.4 & 10.6 & 17.0 & 17.8 \\
\hline 1999 & 13.3 & 25.6 & 18.2 & 22.0 & 16.2 & 9.0 & 14.3 & 17.8 \\
\hline 2000 & 13.3 & 25.6 & 16.8 & 22.3 & 18.1 & 2.6 & 13.7 & 17.8 \\
\hline 2001 & 12.4 & 28.9 & 16.7 & 22.0 & 20.4 & 1.2 & 13.2 & 17.8 \\
\hline 2002 & 12.4 & 28.5 & 16.4 & 20.7 & 21.5 & 1.0 & 14.0 & 21.1 \\
\hline 2003 & 10.9 & 24.9 & 16.9 & 16.3 & 23.5 & 1.0 & 15.4 & 20.7 \\
\hline 2004 & 10.9 & 26.9 & 16.0 & 16.0 & 19.8 & 1.0 & 16.1 & 19.9 \\
\hline 2005 & 10.9 & 26.7 & 15.4 & 14.3 & 18.2 & 1.2 & 16.7 & 21.9 \\
\hline
\end{tabular}

Note: $E E$ - the high share is due to including of gasoline into basket. Source: EBRD (2004); EBRD (2006).

However, other reasons for the significant divergence of the price level in transition countries are suggested (see Skořepa, 2001; Čihák, Holub, 2001; Égert, 2006): $:^{23}$

a) Statistical deception (associated with international comparisons where completely identical items may not exist in the compared countries, in particular clothing or foodstuff can be used as a good example of this phenomenon);

b) Tax burden (indirect taxes, whether general or selective, influence potential commodity arbitration);

c) Speed of arbitration (not a temporary price difference);

d) Arbitration cost (relate to obstacles to arbitration between countries);

e) Existence of monopolist competition on markets with tradable goods (sophisticated products with emphasis on their quality rather than price) $;{ }^{24}$

f) Impact of the population's economic activity (this value for the CR is higher than in other new Member States and most of the old EU Members); ${ }^{25}$

g) Prices of food have not been influenced by the EU agricultural policy (minimum prices, volume regulation, etc.) but instead were influenced by a strong pressure of retail chains over the last few years.

Growth of the economic level in the relevant country leading to changes in the consumer demand structure towards a higher share of non-tradable goods has a very different impact. ${ }^{26}$ The price elasticity in the case of these goods tends to be higher and this ultimately leads to a faster growth in prices.

23 Some of these reasons could be relevant in case of countries of the euro area (Austria or the Netherlands).

24 Lower quality of products would lead to compensatory pressure on export prices depending on demand elasticity.

25 Productivity of the negotiable assets sector is reflected in GDP per worker rather than GDP per capita. Distorted results are generated in the case of different levels of activity in the use of GDP per capita. Relative productivity of the non-negotiable assets sector represents the second factor. Relatively higher productivity decreases unit costs in the negotiable sector and the overall price level.

26 This fact arises from the microeconomic theory of the well-known Engel curve. 
Another possible explanation is linked to the specific situation within the EU (see Canzoneri at al., 1996), where the process of creating a joint market resulted in increased competition in the tradable goods sector. In many cases labour has shifted to the non-tradable goods sector (especially state sector and services), which provides greater protection and barriers against competitive pressures. The growth of this part of the economy has led to higher wage and price growth in countries with higher economic levels. $^{27}$

The price development (nominal convergence) in EU-5 (or more generally in EU-8, EU-10) countries is estimated as a long-term process similarly to real convergence. However, if the rate remains stable, the sector producing non-tradable goods will create positive inflation differential and its extent will depend greatly on development in the prices of tradable goods. Moving from the macroeconomic level to a more detailed structure of good groups (individual items) and assessing the structure of their relative prices and their changes in time would be necessary for a more in-depth analysis. This was the case in the results of the international comparison for the period from 1996 to 1999 (see e.g. Čihák, Holub, 2001); study (see Žd'árek, 2006) has found similar results for 2002 .

\subsection{Path to the Euro Area - Open Issues}

The following few years will be marked especially by the effort to gradually meet the Maastricht convergence criteria. This will be very demanding for stabilising policies. Both, real and nominal convergence of the economy should continue. An acceptable solution that will not jeopardize competitiveness of the corporate sector, while supporting real convergence needs to be sought in respect of nominal convergence.

A number of options exist, considering development of the exchange rate and the price level. The influence of the exchange rate channel will weaken during the stage when the currency exchange rate is fixed as part of the ERM II mechanism. Meeting the Maastricht criteria with regard to inflation will have a different impact on countries with a fixed exchange rate (for whom this will de facto mean free movement within the zone) from countries with a flexible exchange rate (for whom the exchange rate will be fixed in ERM II zones). ${ }^{28}$

In the case of the Czech (Polish and Slovak) economy the exchange rate channel appears to be very significant in recent years (see Table 6). However, we need to consider that the exchange rate is influenced on a short and medium-term basis by a range of

27 The planned change in the conditions for conducting business in the services sector within the EU (the so-called Bolkenstein's directive) should ensure a higher level of competition in this sector. However, the proposed changes have significantly weakened the original intentions and no significant increase in competition in the services sector (or a higher level of negotiability) can therefore be expected.

28 One of the options is modifying the convergence criteria for countries with a fixed exchange rate regime (a higher inflation rate limit) and for countries with a flexible exchange rate regime, as suggested by Dobrinsky (2006). In the case of the inflation criterion differentiation between benign inflation arising from growth of productivity and malign inflation caused by policies should be introduced. 
factors (arrival of investment, expectations, etc.). In a liberalised environment, these capital flows are to a certain extent independent of the actually occurring real economic processes.

As we demonstrated earlier, the relative price level is very low in the case of the new EU Members. Elimination of this gap is a long-term process (connected with the process of real convergence) based on two major channels - the price and exchange rate channels. Questions that have not been so far explained in a satisfactory manner relate to the problem whether fixing the exchange rate in the process of adopting the single currency in these countries with insufficient relative price levels may lead to an increase of inflation differentials on the one hand and to deceleration of the price adjustment process on the other hand. This could lead to deceleration of the process of real convergence and the processes of structural adjustment of economies of these countries.

Table 6

Convergence of Inflation Rates (HICP, annual percentage change)

\begin{tabular}{|l|c|c|c|c|c|}
\hline & $\mathbf{1 9 9 7 - 1 9 9 9}$ & $\mathbf{2 0 0 0 - 2 0 0 2}$ & $\mathbf{2 0 0 3 - 2 0 0 5}$ & $\mathbf{2 0 0 6}$ & $\mathbf{1 9 9 7 - 2 0 0 6}$ \\
\hline EU-27 & 1.4 & 2.1 & 2.1 & 2.2 & 1.9 \\
\hline EU-12 & 1.3 & 2.2 & 2.1 & 2.2 & 1.9 \\
\hline Czech Republic & 6.4 & 3.3 & 1.4 & 2.1 & 3.5 \\
\hline Hungary & 14.2 & 8.1 & 5.0 & 4.0 & 8.5 \\
\hline Poland & 11.3 & 5.7 & 2.2 & 1.3 & 5.8 \\
\hline Slovenia & 7.4 & 8.3 & 4.0 & 2.5 & 6.1 \\
\hline Slovakia & 7.7 & 7.6 & 6.2 & 4.3 & 6.9 \\
\hline Estonia & 7.0 & 4.4 & 2.8 & 4.4 & 4.7 \\
\hline Latvia & 4.8 & 2.4 & 5.3 & 6.6 & 4.4 \\
\hline Lithuania & 5.7 & 1.0 & 0.9 & 3.8 & 2.6 \\
\hline Cyprus & 2.2 & 3.2 & 2.6 & 2.2 & 2.6 \\
\hline Malta & 3.3 & 2.7 & 2.4 & 2.6 & 2.8 \\
\hline
\end{tabular}

Source: EUROSTAT (2007), own calculations.

The process of price convergence can be illustrated by a simple comparison. Table 6 includes inflation rates for new EU Members and Table 5 shows development of their exchange rates. The price channel is already significantly restricted in many of these countries (countries with a specific exchange rate mode, currency board) owing to the efforts to meet the convergence criteria and the selected transitive mechanism of the currency policy (targeted inflation). On the other hand, there is relatively significant appreciation of the exchange rate that has lately occurred (the Czech Republic, Poland) as a main instrument for adjusting the price relations in these economies with low inflation rates. 
Table 7

Development of Nominal Exchange Rate (annual percentage change)

\begin{tabular}{|l|c|c|c|c|c|}
\hline & $\mathbf{1 9 9 7 - 1 9 9 9}$ & $\mathbf{2 0 0 0 - 2 0 0 2}$ & $\mathbf{2 0 0 3 - 2 0 0 5}$ & $\mathbf{2 0 0 6}$ & $\mathbf{1 9 9 7 - 2 0 0 6}$ \\
\hline Czech Republic & -2.2 & 6.2 & 1.2 & 5.1 & 2.1 \\
\hline Estonia & -0.8 & 0.0 & 0.0 & 0.0 & -0.2 \\
\hline Cyprus & 0.7 & 0.2 & -0.1 & 0.2 & 0.3 \\
\hline Latvia & 3.8 & 2.7 & -5.8 & 0.0 & 0.2 \\
\hline Lithuania & 6.1 & 7.4 & 0.1 & 0.0 & 4.1 \\
\hline Hungary & -8.4 & 1.4 & -0.7 & -6.1 & -2.9 \\
\hline Malta & 2.4 & 1.4 & -1.6 & 0.1 & 0.7 \\
\hline Poland & -6.8 & 3.3 & -0.9 & 3.3 & -1.0 \\
\hline Slovenia & -4.0 & -4.9 & -1.9 & -0.0 & -3.3 \\
\hline Slovakia & -4.0 & 1.1 & 3.4 & 3.7 & 0.5 \\
\hline
\end{tabular}

Note: negative value $=$ depreciation .

Source: ECFIN (2007), p. 128-129, own calculations.

A situation where a country's efforts to meet the Maastricht convergence criteria (inflation and exchange rate related) may lead to temporary deceleration of the convergence processes and their restoration following the adoption of the single currency may result in a significant increase in inflation rates presents yet another problem. ${ }^{29}$ This phenomenon has been observed in the case of less developed EU Member States (Spain, Portugal and Greece), but also in the case of the dynamic Irish economy.

The overall price level (GDP) of Portugal to the EC average level (EC-10) was around $55 \%$ at the time of its accession (1986) and approximately $70 \%$ in 1996 (goods and services for individual consumption increased from $60 \%$ to $74 \%$ in the same period). During the same period, Spain recorded a lower rate of growth from $76.9 \%$ to $85 \%$ of the average level, while Greece practically stagnated from $83.3 \%$ (1981) to $80 \%{ }^{30}$ Nominal convergence of these countries gradually adjusted and has been at a level equal to the economic level on a long-term basis (no significant divergences are observed). However, a more detailed structure of price relations and the adjustment process as such has not been and will not be completed for quite some time. ${ }^{3}$

Groups of countries with inflation differentials higher than the euro area average (not only countries at a lower economic level - Mediterranean countries - but also Ireland or the Netherlands), as well as countries with inflation rates below this level exist within the EU. States with higher inflation rates also recorded higher growth rates. Their low price levels are therefore associated with the risk of increased inflation (as was the case for example in Mediterranean countries which compensated price

29 This is the so-called boxer effect highlighted in the work of Szapáry (2000). For example Brook (2005) discusses this effect with regard to selected EU countries.

30 Numbers vary depending on the method of constructing the average for all countries during the relevant period (EC-10 or EC-12). This is why these values must be considered only approximate price level indicators. See e.g. Janáčková (2000), Nestić (2005).

31 In order to examine this issue in greater detail, development of individual items in the main consumption groups would need to be monitored and tested. 
differentials with a fixed rate arising from different growth rates of productivity in this manner). Experience of certain countries suggests potential danger of holding back the economic growth associated with anti-inflation stabilising policies applied in these countries. $^{32}$

Table 8

Differences in HICP and GDP before and after Entry into the Euro Area (annual percentage changes)

\begin{tabular}{|c|c|c|c|c|c|c|c|c|}
\hline & \multirow{2}{*}{\multicolumn{2}{|c|}{$\begin{array}{c}\begin{array}{c}\text { Before entering the } \\
\text { euro area }\end{array} \\
1996-1998 \\
\end{array}$}} & \multicolumn{6}{|c|}{ Within the euro area } \\
\hline & & & \multicolumn{2}{|c|}{ 1999-2001 } & \multicolumn{2}{|c|}{ 2002-2004 } & \multicolumn{2}{|c|}{ 2005-2006 } \\
\hline & HICP & GDP & HICP & GDP & HICP & GDP & HICP & GDP \\
\hline Ireland & 1.8 & 9.5 & 3.9 & 8.6 & 3.7 & 4.9 & 2.4 & 5.7 \\
\hline Netherlands & 1.7 & 3.7 & 3.1 & 3.5 & 2.5 & 0.8 & 1.6 & 2.2 \\
\hline Portugal & 2.3 & 4.2 & 3.1 & 3.3 & 3.2 & 0.5 & 2.0 & 0.9 \\
\hline Greece & 5.9 & 3.1 & 2.9 & 4.3 & 3.4 & 4.4 & 3.4 & 4.0 \\
\hline Spain & 2.4 & 3.6 & 2.8 & 4.4 & 3.3 & 3.0 & 3.5 & 3.7 \\
\hline
\end{tabular}

Source: Structural Indicators, EUROSTAT (2007), own calculations.

EU countries with lower economic levels (or significant structural changes) listed in Table 8 can be used as an example. Except for Greece, which did not join the euro area in 1999 with the other 11 countries and strived to meet the Maastricht criteria, all other countries displayed a higher price growth during 1999-2001 than during the previous stage (1996-1998) with a decreased GDP growth rate (except for the above-mentioned Greece and Spain). This higher growth of prices persisted even in the following period (2002-2004), although the lower growth dynamics during this period were influenced by a number of adverse external factors.

Experience of countries that became EU Members during the 1980s and 1990s may prove very practical in this case. This applies especially to the Mediterranean countries (Portugal, Greece and Spain), which had comparable real (and nominal) levels upon their accession to the EU to that of the CR. These countries experienced dynamic development before and after their accession. Experience of countries that became Members of the Community in the 1980s is very useful to the current new Member States from a number of aspects (the course, progress, reactions of entities, etc.). Ireland could also be considered as a country at an identical level upon accession to the Community. However, this country does not match the selected examples due to its specific characteristics (language, location, etc.) and therefore will be excluded from this consideration; states involved in the previous wave of extension in 1995 will also be excluded.

Even other countries differ from the current new EU-8 states, to be more specific Portugal due to its history of an industrially and agriculturally backward country, Greece influenced by the prolonged unrest in the country (and once again a large share

32 The disinflation process is connected with loss of product (although the growth rates may be positive) in respect of the potential product. It is therefore possible to conclude a static and dynamic sacrifice ratio of this disinflation process for the relevant economy. 
of agriculture in the national economy) and Spain as a country coming out of a prolonged period of an authoritarian regime. However, Spain's economic level and structure is significantly closer to the current one and therefore the most significant for our purposes.

\section{Conclusion}

After the fall at the beginning of the 1990s, economies of the EU-8 countries gained significant dynamics, which allowed them to renew the real convergence process. Some of the countries did not manage to avoid certain deceleration in the mid 1990s or at the turn of the century. The Czech Republic holds one of the leading positions (after Slovenia) regarding GDP per capita in the purchasing power parity and the first place among the EU-8 countries in the real convergence rate during 2000-2006.

The significant divergence of the price level in the economy from the value expected in respect of the achieved economic level in the $\mathrm{CR}$ represents a major potential problem for the Czech economy. A number of factors that may influence this status have been mentioned in this paper as the frequently discussed issue of price regulation is not sufficient. This fact is a relatively serious economic problem not only for the present times but especially for future development of the economy as a whole. The price level of the Czech economy will continue to grow over the next few years not only owing to the inflation differential and the exchange rate, but also due to spontaneous processes. The price level growth will result from growing labour productivity and real income, and the convergence tendency in consumer habits.

The disaggregated approach to comparative price level indexes revealed important consequences. The most often used regression in the real and nominal convergence process shows the slope of comparative prices level to GDP per capita in PPS near 0.8-0.9. If we do disaggregated approach, we get absolutely different results. The expected real convergence process will cause the increase in comparative prices level through the price increase in services, where the slope to GDP per capita is higher than in comparative price level for total goods.

Significant progress in price convergence and adjustment of the price structure to the European average can be observed. The adjustment of price levels in the case of countries such as the Czech Republic or Slovakia was influenced by the movement of exchange rate rather than the inflation differential. It can be expected that the remaining price difference will also be gradually eliminated mainly through movement of the exchange rate. However, this poses a potential problem in entering the ERM II and the necessity to maintain a specified range of exchange rate movement in relation to the central parity.

Estimating exactly how long the process of price convergence may take is impossible for a number of reasons (especially due to the difference between tradable and non-tradable goods). Experience of less developed countries that joined the European Union in the 1980s or the formerly poor Ireland suggests the same. This is because certain autonomous (spontaneous) factors play their role in the process besides the price and exchange rate channel mentioned above. Development of real income per capita, real income, and labour productivity in the Czech economy in relation to other 
countries will be the main determinants. However, this is a matter concerning a few decades into the future.

Securing relatively smooth progress of the convergence process requires harmonised progress of convergence of real and nominal values. However, a number of unsolved issued remains in the area of nominal convergence and these issues will need to be solved in a satisfactory manner sooner or later (the impact of B-S effect, etc.). Their significance will increase with the approaching date of accession to the euro area.

\section{References}

Balassa, B. (1964), "The Purchasing-Power Parity Doctrine: A Reappraisal." The Journal of Political Economy, December, No. 6, pp. 584-596.

Barro, R. J. (1991), "Economic Growth in a Cross Section of Nations." Quarterly Journal of Economics, No. 2, pp. 407-433.

Barro, R. J., Sala-i-Martin, X. (2004), Economic Growth. 2nd Ed. Cambridge : MIT Press.

Brook, A.-M. (2005), "The challenges of EMU accession faced by catching-up countries: A Slovak Republic case study." OECD Economic Department Working Paper No. 444, September.

Canzoneri, M. B., Diba, B., Eudey, G. (1996) "Trends in European Productivity and Real Exchange Rates: Implications for the Maastricht Convergence Criteria and for Inflation Targets after EMU." London: CEPR, Discussion Paper No. 1417.

Čihák, M., Holub, T. (2001), "Cenová konvergence k EU - pár nezodpovězených otázek." Finance a úvěr, No. 6, pp. 331-349.

Dědek, O. (2002), "Česká ekonomika a euro." Politická ekonomie, No. 3, pp. 361-375.

Dobrinsky, R. (2006), "Nominal versus Real Convergence: The Balancing Act for New EU Entrants." Mimeo, WIIW Spring Seminar Wider Europe: Opportunities and Future Challenges, Vienna, March 2006.

EBRD (2004), Transition Report 2004. Infrastructure. London : EBRD.

EBRD (2006), Transition Report 2006. Finance in transition. London : EBRD.

EC (2005), “Convergence Report 2004. European Economy." Luxemburg : European Commission, DG ECFIN. Special Report No. 2.

ECB (1999), "Monthly Report." Frankfurt a. M. : ECB, No. 44, October.

ECB (2007), "Monthly Report." Frankfurt a. M. : ECB, January.

ECFIN (2007), "Statistical Annex of European Economy." Brussels : DG ECFIN, Spring 2007.

Égert, B. (2003), "Nominal and real convergence in Estonia: The Balassa-Samuelson (dis)connection. Oil shale, tradable goods, regulated prices and other culprits." William Davidson Institute Working Paper, No. 556, April.

Égert, B. (2006), "Real Convergence, Price Level Convergence and Inflation." Paper presented at conference ICEG EC: Growth and Jobs: Challenges to the Lisbon Strategy and European Competitiveness, Budapest, April 2006.

EUROSTAT (2003), "Clothing and footwear - comparative price levels in EU, EFTA and Candidate Countries for Luxemburg." Statistic in focus, No. 13 (a).

Luxemburg : EUROSTAT.

EUROSTAT (2005), "Changes to National Accounts in 2005." Luxemburg : EUROSTAT. Downloadable: europa.eu.int/estatref/info/sdds/en/na/na_changes2005.pdf (15. 2. 2006) (b).

EUROSTAT (2006), "Relative price levels for new passenger cars in Europe for 2004." Statistic in focus, No. 3 (a). Luxemburg : EUROSTAT.

EUROSTAT (2007), "Structural Indicators. National accounts." Luxemburg : EUROSTAT.

EUROSTAT (2007), "Prices." Luxemburg : Eurostat Economy and Finance Database.

Frait, J., Komárek, L. (2004), "Exchange Rate and Monetary Developments in Accession Countries," in Polouček, S., ed., Reforming the Financial Sector in Central European Countries. Houndmills, Basingstoke : Palgrave Macmillan, pp. 169-210.

Galor, O. (1996), "Convergence? Inference form Theoretical Models." The Economic Journal, 106 (437), pp. 1056-1069.

Greene, W. H. (2003), Econometric analysis. 5th Ed. Upper Saddle River : Prentice Hall. 
Holub, T., Čihák, M. (2003), "Price Convergence: What Can Balassa-Samuelson Model Tell Us?" Praha : ČNB, Working Paper No. 8.

Janáček, K., Janáčková, S. (2004), "Evropská měnová unie a rizika pro reálnou konvergenci." Politická ekonomie, No. 4, pp. 435-449.

Janáčková, S. (2000), "Price convergence and the Readiness of the Czech Economy for Accession to the European Union." Eastern European Economics, (38) 4, pp. 73-91.

Kočenda, E., Kutan, A. M., Yigit, T. M. (2006), "Pilgrims to the Eurozone: How far, how fast?" Economic Systems, (30) 6, pp. 311-327.

Kovács, A. M., ed. (2002), "On the estimated size of the Balassa-Samuelson effect in five Central and Eastern European countries." Nation Bank of Hungary, NBH Working Paper No. 5.

Lojschová, A. (2003), "Estimating the Impact of the Balassa-Samuelson Effect in Transition Economies." Vienna : HIS, Economic Series No. 140.

Mihaljek, D., Klau, M. (2003), "The Balassa-Samuelson Effect in Central Europe: A Disaggregated Analysis." BIS Working Paper No. 143.

Nestić, D. (2005), "Price Level Convergence: Croatia, Transition Countries and the EU." Croatian National Bank Working Papers W. 13, 38 p.

Obsfeld, M., Rogoff, K. (1998), Foundation of International Macroeconomics. Cambridge, MA : MIT Press.

Rogoff, K. (1996), "The Purchasing Power Parity Puzzle." Journal of Economic Literature, No. 2, pp. $647-668$.

Rother, P., Süppel, R. (2003), "East Germany, Central Europe, and Risk of Real Convergence Overshooting." Finance a úvěr, No. 9-10, pp. 374-393.

Samuelson, P. A. (1964), "Theoretical Notes on Trade Problems." The Review of Economics and Statistics, No. 2, pp. 145-154.

Skořepa, M. (2001), "K rozdílům v cenových hladinách mezi ČR a Německem." Finance a úvěr, No. 6 , pp. 350-363.

Slavík, C. (2005), "Reálná konvergence České republiky k EU v porovnání s ostatními novými členskými zeměmi." Praha : CESES UK.

Spěváček, V., Vintrová, R., Hájek, M., Žd’árek, V. (2006), "Makroekonomický vývoj České republiky v letech 1996-2004." Politická ekonomie, No. 2, pp. 147-169.

Sorsa, P. (2006), "Macroeconomic Challenges with EU Accession in Southeastern Europe: An Overview." Washington, DC : IMF, Working Paper No. 40.

Szapáry, G. (2000), "Maastricht and the Choice of Exchange Rate Regime in Transition Countries During the Run-up to EMU." NBH Working Paper No. 7.

UNECE (2001), "Economic Survey of Europe." New York; Geneva : United Nations.

Vávra, D. (1999), "Nominal versus real convergence in a CEE transition country: Do the Maastricht criteria make sense for the Czech Republic?" Prague : CERGE-EI Discussion Paper Series No. 16.

Vintrová, R. (2005), "What GDP Indicators Do Not Tell You: Alternative Indicators of Economic Growth and Real Convergence." Finance a úvěr, No. 11-12, pp. 579-595.

WB (2006), "EU8 Quarterly Economic Report." Warsaw : World Bank, February 2006.

Žd'árek, V. (2006), "Nominální konvergence v České republice - vybrané aspekty a důsledky." Working Paper CES VŠEM č. 6. 